\title{
Characteristics Biolubricant Enriched with Nanoparticle Additives: a Review
}

\author{
Zhahra Hanif Sholiha*, Gaguk Jatisukamto \\ Department of Mechanical Engineering, Faculty of Engineering, University of Jember, Jember, \\ 68121, East Java, Indonesia \\ *Corresponding author:zhahrahanifsholiha95@gmail.com
}

\begin{abstract}
The engine movement mechanism is a system composed of machine elements that contact or rub against each other between these surfaces. Surfaces that rub against each other will cause a friction force that causes wear on the surface, so it requires energy to fight the friction force. Lubricants are needed to reduce friction and reduce wear rates, where lubricants are generally made of mineral materials. Lubricants made from synthetic materials are non-renewable and cause environmental problems. The development of biolubricants as lubricating materials based on animal fats or vegetable oils is continuously being carried out. This study aims to observe the potential of biolubricants based on reviews from various previous research journals. The use of additives in biolubricants is also studied whether the addition of these additives can improve the characteristics of biolubricants. This study shows that the addition of certain additives to biolubricants can improve the characteristics of biolubricants.
\end{abstract}

Copyright (C) 2020. Journal of Mechanical Engineering Science and Technology

All rights reserved

Keywords: Biolubricant, coefficient of friction, lubricants, viscosity, wear rate

\section{Introduction}

Improving a friendly environment and efficiency resistance is important in the engine movement mechanism. Development of biolubricants as environmentally friendly lubricants continues to be developed to meet green tribology standards. The use of mineral-based lubricants is generally dominated by the automotive sector, which is about $80 \%$, while the rest comes from synthetic materials and other materials [1]. The lubricating properties of mineral materials are non-renewable and can cause environmental problems. Research studies on lubricants from biological materials are continuously being carried out in order to obtain lubricants from biological materials that are better than lubricants from mineral substances. Sources of lubricants from biological materials consist of soybeans, cocoa, coconut, jatropha, palm oil, which generally can be grown in tropical areas [2]. Biolubricants play an important role in supporting the green tribology program. Green tribology is green tribology, namely the coverage of tribology related to friction, wear and lubrication to support environmental sustainability. The United States has used one-third of its energy needs to deal with energy caused by friction. The greater the frictional energy in a movement mechanism will lead to greater energy consumption and the resulting environmental impact [4]. The main review of green tribology aims to preserve and improve the quality of the environment and avoid global warming [5].

The criteria and characteristics of a lubricant must meet six basic standards, namely: viscosity index, total base number, pour point, flash point [6]. Biolubricant which has a low 
viscosity value can be improved by adding additives, its characteristics as a biolubricant become better. Lubricant is a substance that is applied between two surfaces in contact with each other to reduce the friction force and wear rate on the two surfaces [7]. Research on the use of cultivable biological materials as biochemical base materials continues to be studied. Lubricant substitution from biological materials as a substitute for mineral materials continues to be developed to preserve nature and to increase public awareness of the importance of a green environment [8]. Lubricating materials with nano-scale particles are very intensively developed so that the lubricants can reduce friction and wear. The lubrication mechanism is divided into two types: (a) Direct lubrication mechanism and (b) Indirect lubrication mechanism.

Nanoparticles are added to lubricating oil to improve its tribological properties, which can reduce the coefficient of friction and wear [9]. Figure 1. shows the lubrication mechanism between two contact surfaces for nano particle lubricants.

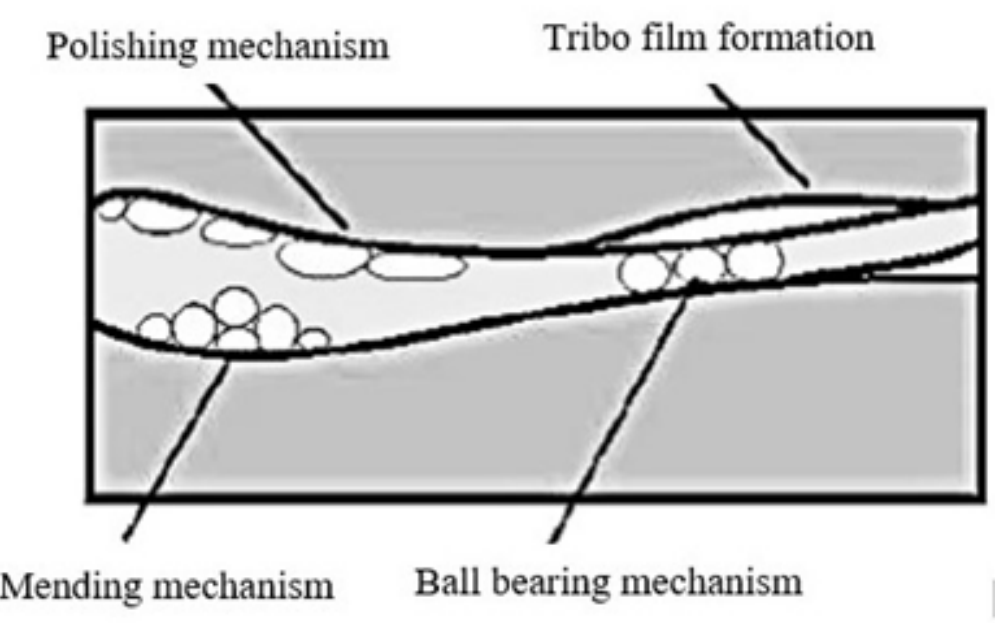

Fig. 1. Lubrication mechanism on two contact surfaces for lubricating nanoparticles [9].

The basic ingredients for the manufacture of lubricants are classified into three types, namely mineral lubricants, synthetic lubricants and also biolubricants (vegetable oils and animal oils). Biolubricant was used as a test material in this study. Biolubricant, namely animal and vegetable lubricants obtained from animal and plant fats. Lubricants are generally made from mineral oil. The difference between mineral lubricants and animal and vegetable lubricants is that animal and vegetable oils contain unsaturated compounds [10]. The advantage of biolubricant lies in its ability to lubricate and has good properties on wet and humid surfaces when compared to mineral oil. The lubricant layer will provide effective protection against friction. The use of vegetable lubricants are expected to improve the characteristics of lubricants that are environmentally friendly.

\section{Research on Lubricants}

\section{a. The Effect of Lubricant Variation on Viscosity and Coefficient of Friction and Wear Rate}

The main function of a lubricant is to reduce friction and wear that occurs on moving objects rubbing against each other. The science of tribology is a very important part of knowing the characteristics and its application in the engineering field [11]. Tribology is the 
science of friction, wear, and lubricants. Viscosity is one of the physical properties of a lubricant which indicates the viscosity of the lubricant [12]. The viscosity of the lubricant affects the friction efficiency of the contact surface. The greater the viscosity of a lubricant, the greater the drag force. Stokes law states that a large viscosity causes a large friction force [13]. The friction force is proportional to the viscosity value of the lubricant. Based on the equations of the friction mechanism formula and the Stokes law, the coefficient of friction is inversely proportional to the friction force and viscosity [14-15].

Table 1. Variations in viscosity and coefficient of friction and wear rates [16-21]

\begin{tabular}{lccc}
\hline Lubricant & $\begin{array}{c}\text { Viscosities } \\
(\mathrm{cSt}) \text { @ 100C }\end{array}$ & Friction (coF) & Wear (mm) \\
\hline SAE 10W/40 & 4.700 & 0.108 & 0.510 \\
SAE 15W/40 & 6.500 & 0.105 & 0.500 \\
SAE 20W/40 & 7.800 & 0.107 & 0.510 \\
Mineral Oil & 13.689 & 0.093 & 0.765 \\
SAE 40 & 15.000 & 0.114 & 0.520 \\
Soybean Oil & 7.889 & 0.112 & 4.998 \\
Palm Oil & 8.644 & 0.105 & 4.175 \\
Jatropha Oil & 8.040 & 0.095 & 3.000 \\
Stamping Oil & 11.400 & 0.075 & 0.650 \\
\hline
\end{tabular}

Research on the correlation between the viscosity of $100^{\circ} \mathrm{C}(\mathrm{cSt})$ and the coefficient of friction (coF) can be seen in Figure 2. The graph shows that the greater the viscosity value of a lubricant causes the lower friction coefficient value. The results of research regarding the correlation of viscosity and friction coefficient are in line with the equation of the friction mechanism and the law of Stokes, namely the greater the viscosity value, the smaller the friction coefficient value. The results of the wear test research can be seen in Figure 3. The graph shows the same trendline as Figure 2, namely the greater the viscosity value of a lubricant, the lower the wear value [16-21].

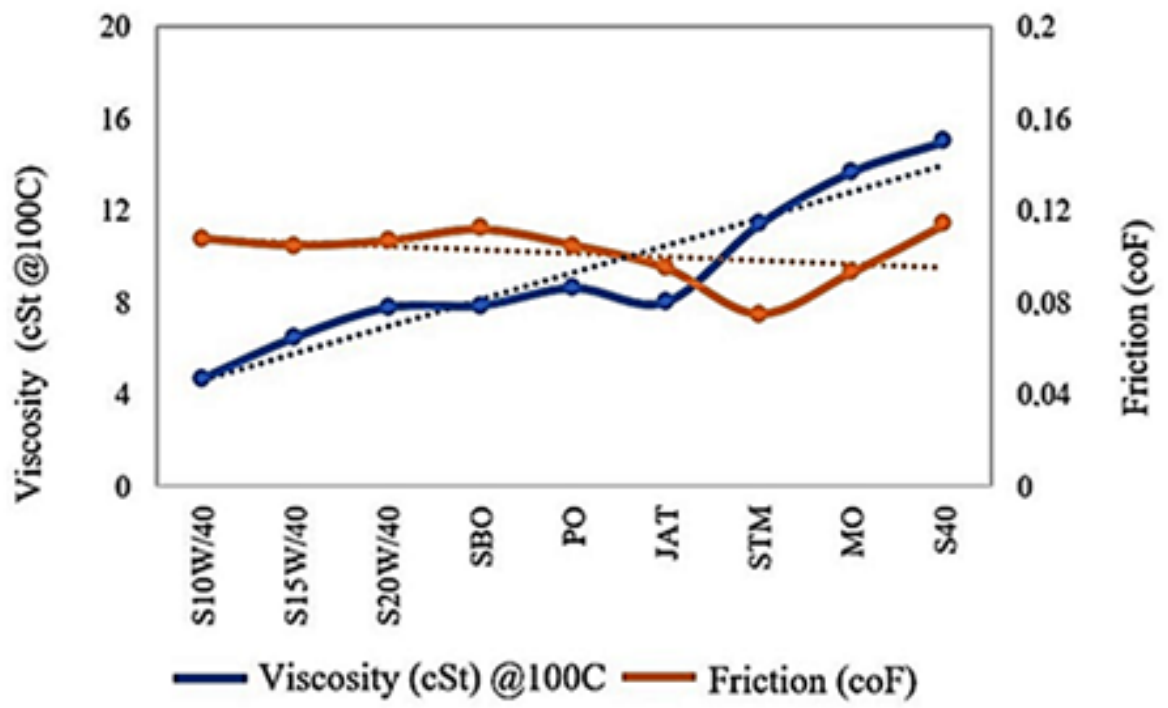

Fig. 2. Graph of Viscosity - Coefficient of friction [16-21] 


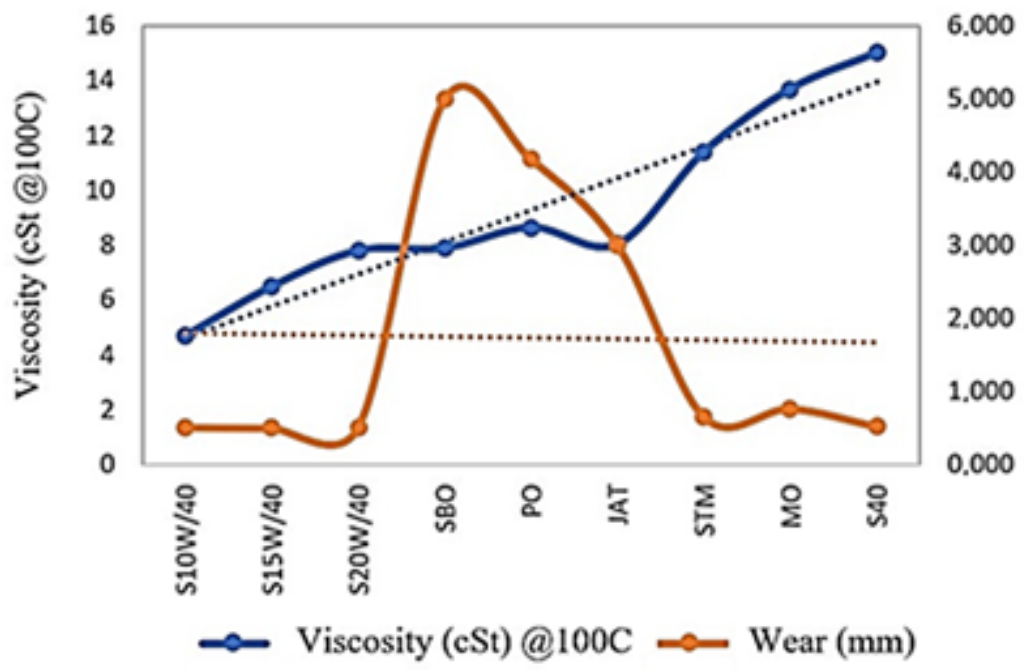

Fig. 3. Graph Viscosity - Wear [16-21]

\section{b. Effect of Additives on Characteristics}

Armuggam et al. [22] studied the effect of Rappassed Oil plus $\mathrm{TiO}_{2}$ additives and found that the power value was reduced by $15 \%$. Biolubricant based on vegetable oil added with $\mathrm{TiO}_{2}$ additive experienced a $58.1 \%$ decrease in wear value from pure organic oil [24]. Charo et al. [23] investigated mineral oil SAE 10W30 plus additive $\mathrm{MoS}_{2}$ obtained 20\% reduced wear value. Mineral Soybean Oil coupled with $\mathrm{CuO}$ additives resulted in a reduced wear value of $12 \%$ [24]. Paraffinic oil with the additive $\mathrm{MoS}_{2}$ decreased the coefficient of friction by $64 \%[25]$.

Table 2. Effect of additives on biolubricants on decreasing friction coefficient and decreasing wear rate [24-28]

\begin{tabular}{llcl}
\hline Lubricant & Additives & $\begin{array}{c}\text { Reduction of } \\
\text { friction }\end{array}$ & $\begin{array}{c}\text { Reduction of } \\
\text { wear }\end{array}$ \\
\hline Paraffinic Oil & $\mathrm{MoS}_{2}$ & $64 \%$ & - \\
Vegetable Oil & $\mathrm{TiO}_{2}$ & - & $58.1 \%$ \\
Rapeseed Oil & $\mathrm{CuO}$ & $40 \%$ & - \\
Rapeseed Oil & $\mathrm{TiO}_{2}$ & - & $15 \%$ \\
Palm Oil & $\mathrm{TiO}_{2}$ & $15 \%$ & $11 \%$ \\
SAE 10W30 & $\mathrm{TiO}_{2}$ & - & $15 \%$ \\
SAE 20W40 & $\mathrm{MoS}_{2}$ & - & $20 \%$ \\
SAE 5W30 & $\mathrm{MoS}_{2}$ & $50 \%$ & - \\
Polyalphaolefins & $\mathrm{MoS}_{2}$ & $40 \%$ & - \\
Soybean Oil & $\mathrm{CuO}_{\text {SuO }}$ & - & $12 \%$ \\
SAE 10W40 & $\mathrm{Titanium}_{\text {SAE 20W40 }}^{\mathrm{Graphene}}$ & $32 \%$ & - \\
SAE 15W40 & oxide & $32 \%$ & - \\
\hline
\end{tabular}


Sharma et al. [26] studied vegetable oil with $\mathrm{TiO}_{2}$ added to get a reduced wear value of up to $58.1 \%$ compared to pure oil. Rapessed oil with added $\mathrm{CuO}$ additives decreased the coefficient of friction by $40 \%$ [26]. Sgroi et al. [27] studied synthetic oil SAE 5W30 added with $\mathrm{MoS}_{2}$ additives to get a decrease in the value of the friction coefficient of $50 \%$. Polyalphaolefins added with the additive $\mathrm{MoS}_{2}$ resulted in a $40 \%$ reduction in the strength value [28]. Singh et al. 2019 [29] examined the tribological performance of SAE 10W/40 and SAE20W/40 lubricants with the addition of titanium additives and graphene oxide. These additives can reduce the friction coefficient by $32 \%$. Improved friction behavior of SAE $15 \mathrm{~W}-40$ lubricants with the addition of graphite particles. The addition of graphite to SAE 15W-40 lubricant can reduce the friction coefficient from 33-36\% [29].

\section{c. Characteristic Biolubricant}

Characteristics of biolubricant can be observed from the test results. There are several characteristics in a biolubricant, namely Kinematic viscosity, Viscosity index, Total base number. The characteristic values of some biolubricants are shown in Table 3.

Table 3. Characteristics biolubricant [30]

\begin{tabular}{lccccc}
\hline Properties & Soybean oil & Sunflower Oil & Rapeseed Oil & Castor Oil & Palm Oil \\
\hline $\begin{array}{l}\text { Kinematic viscosity } \\
\text { @ } 40^{\circ} \mathrm{C}(\mathrm{cSt})\end{array}$ & 32.93 & 40.05 & 45.6 & 220.6 & 40.24 \\
$\begin{array}{l}\text { Kinematic viscosity } \\
\text { @ } 100^{\circ} \mathrm{C}(\mathrm{cSt})\end{array}$ & 8.08 & 8.65 & 10.07 & 19.72 & 7.89 \\
Viscosity Index & 219 & 206 & 216 & 220 & 110 \\
Total base number & 0.61 & - & 1.4 & 1.4 & - \\
$(\mathrm{mgKOHg}-1)$ & & & & & \\
Pour point $\left({ }^{\circ} \mathrm{C}\right)$ & -9 & -12 & -12 & -27 & -21 \\
Flash point $\left({ }^{\circ} \mathrm{C}\right)$ & 240 & 252 & 240 & 250 & 220 \\
\hline
\end{tabular}

\section{d. Test Methods}

The method in testing that can be used to evaluate the tribological properties of a lubricant can be seen in Table 4, done by various researchers on lubricating oil.

Table 4. Summary of test methods [31-35]

\begin{tabular}{ll}
\hline Lubricant & Test Methods \\
\hline $\begin{array}{l}\text { Variation of lubricants: } \\
\text { (1) Lubricant SAE 40; (2) Jatropha oil } \\
\text { (mixture) } 1 \%, 2 \%, 3 \%, 4 \%, 5 \%\end{array}$ & Four ball tribotester \\
\hline $\begin{array}{l}\text { Variation of lubricants: } \\
\text { (1) Lubricant oil; (2) Parafin oil; (3) }\end{array}$ & Four ball tribotester \\
Biolubricant + TiO 2 & \\
\hline $\begin{array}{l}\text { Variation of lubricants: } \\
\text { (1) Commercial oil stamping; (2) Comercial } \\
\text { oil hydraulic; (3) Jatropha oil; (4) RBD palm } \\
\text { oil; (5) Palm fatty acid }\end{array}$ & Four ball tribotester \\
\hline $\begin{array}{l}\text { Variation of lubricants: } \\
\text { (1) Mineral oil; (2) Synthetic oil; (3) } \\
\text { Biolubricant }\end{array}$ & Comparison of data and results of previous research \\
\hline Variation of lubricants: & \\
\hline
\end{tabular}


Test Methods

(1) Jatropha Oil; (2) RBD Palm Olein; (3)

Palm Fatty Acid Distillate; (4) Stamping oil;

(5) Hydraulic oil

Variation of lubricants:
1. Crude Jatropha Oil / CJO
2. Syntethic ester $(\mathrm{SE})$
3. MJO1 (JME:TMP $=3.1: 1)$
4. MJO3 (JME:TMP $=3.3: 1)$
5. MJO5 (JME:TMP $=3.5: 1)$

Fourball tester based on ASTM D4172

Variation of lubricants:

(1) Soybean oil; (2) Sunflower oil; (3) Jatropha oil; (4) Palm oil; (5) Jojoba oil

Variation of lubricants:

1. SAE $10 \mathrm{~W} 40$

2. SAE $20 \mathrm{~W} 40$

Variation of lubricants:

1. Jatropha oil / SJO (100)

2. Mineral oil / EMO (100)

3. B20 (SJO 20 : EMO 80)

\begin{tabular}{ll}
\hline Variation of lubricants: & 1. Ring compression test \\
1. Soybean oil & 2. Finite element simulation \\
2. Sunflower oil & \\
\hline
\end{tabular}

Variation of lubricants:

1. SAE40

1. Cygnus wear testing four ball Tester

2. JO10 (Jatropha oil 10\%: SAE40 90\%)

3. JO20 (Jatropha oil 20\% : SAE40 80\%)

4. JO30 (Jatropha oil 30\% : SAE40 70\%)

5. JO40 (Jatropha oil 40\% : SAE $4060 \%$ )

6. JO50 (Jatropha oil 50\% : SAE $4050 \%$ )

Variation of lubricants:

1. SAE40 $80 \%$ + Molybdenum

Dysulfide $20 \%$

Variation of lubricants:

1. SAE 40

2. Palm oil

Variation of lubricants:

1. Canola oil $+1.5 \%$ graphene

Comparison of data and result of previous research

The preparation method is by adding nanoparticles as a synthesis material, a four ball tester and data comparison of previous research results

Four ball tribotester

Variation of lubricants:

1. Mineral oil (5CST)

2. Biolubricant (RSO)

Electrostatic charge solid lubricant spray techniques

Observation of tool temperature, wear and surface roughness of the lathe is a basic reference for research.

Observation of the properties and results of grinding using a precision machining process

1. KEYENCE vk-x200 laser scanning microscope (CLSM)

2. X-ray absorption near edge structure spectroscopy (XANES)

3. Fluorescence yield (FY)

4. Total electron yield (TEY)

Variation of lubricants:

Linear reciprocating tribometer

1. SAE $15 \mathrm{~W}-40$

2. SAE $15 \mathrm{~W}-40+$ graphite

Variation of lubricants:

1. Jatropha oil + Ethylcellulose (CO/EC)

2. Sunflower oil + Ethylcellulose (HOSO/EC)

1. Measurement of density and viscosity using a controlled-strain rotational rheometer

2. Temperature analysis using differential scanning calorimetry

Research on tribological properties using EHL and stribeck-curve.

Variation of lubricants:

Fourball Tester based ASTM D4172 and ASTM D2783

1. SAE $15 \mathrm{~W}-40$

2. SAE $20 \mathrm{~W}-50$ 


\begin{tabular}{ll}
\hline Lubricant & Test Methods \\
\hline Variation of lubricants: & Measure smoke emission levels using the AVL 43 smoke \\
1. Biofuel + SAE 20W-40 & meter and AVL DI gas analyzer \\
2. Biofuel + biolubricant rapeseed & \\
\hline Variation of lubricants: & Engine test use 43cc brush cutter 2-stroke engine \\
1. Mineral oil - Additives & \\
2. Mineral oil + 10\% TMPTO - T10 & \\
$\quad$ Trimethylolpropane Trioleate) & \\
3. Mineral oil + 15\% TMPTO - T15 & \\
4. Mineral oil + 20\% TMPTO - T20 & \\
5. Mineral oil + 50\% TMPTO - T50 & Four ball tribotester \\
\hline Variation of lubricants: & \\
1. Jatropha oil / SJO (100) & \\
2. Mineral oil / EMO (100) & \\
3. B20 (SJO 20 : EMO 80) &
\end{tabular}

\section{Conclusions}

Based on previous research studies on the use of additives in biolubricants, the following conclusions are the vegetable oil derived from plants can be used as a biolubricant, but pure biolubricant has a low viscosity so that the lubricant function as a film layer between two contact surfaces is lower when compared to mineral oil; Additives need to be added to pure biolubricants to improve their viscosity, so as to reduce the friction coefficient and wear rate on the contact surface; The ability of additives to improve biolubricant characteristics varies greatly depending on the type of biolubricant and additives used; The addition of $\mathrm{MoS}_{2}$ additives to paraffinic oil can reduce the value of the largest coefficient of friction, namely $64 \%$, when compared to the combination of additives + biolubricants as follows: $\mathrm{TiO}_{2}+$ Vegetable Oil; $\mathrm{CuO}+$ Rapeseed Oil; $\mathrm{TiO}_{2}$ + Rapressed Oil; $\mathrm{TiO} 2$ + palm oil.

\section{Acknowledgment}

I gratefully acknowledge all the researchers in the field of Tribology. Without their contribution, this review would have been difficult to do.

\section{References}

[1] Talib, N., and Rahim, A., "The Effect of Tribology Behavior on Machining Performances When Using Bio-Based Lubricant as a Sustainable Metalworking Fluid", Procedia CIRP 40, pp. 504-508, 2016.

[2] Bahari, A., Lewis R., and Slatter,T., "Friction and wear response of vegetable oils and their blends with mineral engine oil in a reciprocating sliding contact at severe contact conditions," Proc. IMech: Journal of Engineering Tribology, Part J., pp. 1-15, 2017.

[3] Leksono, B., Windyarini, E., and Hasnah, T.M., Budidaya Nyamplung (Calophyllum Inophyllum L.) Untuk Bioenergi dan Prospek Pemanfaatan Lainnya, Bogor: IPB Press, 2014. 
[4] Nosonovsky, M., and Bushan, B., "Green Tribology: principle, research areas and challanges," Philosophical Transactions of the Royal Society of London A: Mathematical, Physical and Engineering Sciences, pp. 4677-4694, 2010.

[5] Zhang, S., "Friction", Green tribology: Fundamentals and future development, pp. 186-194, 2013.

[6] ASTM, D 2270 - 04, Standard Practice for Calculating Viscosity Index from Kinematic Viscosity at 40 and $100^{\circ} \mathrm{C}$, ASTM International, 2009.

[7] Zheng, G., Ding, T., Huang, Y., Zheng, L., and Ren, T., "Fatty acid based phosphite ionic liquids as multifunctional lubricant additives in mineral oil and refined vegetable oil," Tribology International, vol. 123, pp. 316-324, 2018.

[8] Mang, T., and Dresel, W., Lubricant and Lubrications. Weinheim: WileyVCH Verlag GmbH \& Co., 2007.

[9] Srivyas, P. D., and Charoo, M. S., "A Review on Tribological Characterization of Lubricants with Nano Additives for Automotive Applications", Tribology in Industri, pp. 594-623, 2018.

[10] Mawardi, M. S., Pembuatan Pelumas-bio dari Asam Oleat Dengan Esterifikasi Menggunakan Katalis Asam Phosphotungstat/Zeolit. Skripsi, Unpublished, Depok, 2008.

[11] Gunstone, F. D., and F. B. Padley., Lipid Technologies and Applicatios, CRC Press, 1997.

[12] Naughton, F. C.,'Castor Oil"'. in Kirk-Othmer Encyclopedia of Chemical Technology, John Wiley \& Sons, 2011.

[13] Chapra, S. C., and Canale, R. P., Numerical Methods for Engineers, New York: McGraw-Hill, 2010.

[14] ASTM, G 99-95a (Standard Test Method for Wear Testing with a Pin-on-Disk Apparatus), ASTM International, pp. 1-6, 2000.

[15] Lim, S., and Ashby, M. F., "Wear-mechanism maps", Acta Metall, pp. 1-24, 1987.

[16] ASTM, D 2270 - 04 (Standard Practice for Calculating Viscosity Index from Kinematic Viscosity at 40 and $100^{\circ} \mathrm{C}$ ), ASTM International, 2009

[17] Guo, J., Peng, R., Du, H., Shen, Y., Li, Y., Li, J., \& Dong, G., "The Application of Nano-MoS 2 Quantum Dots as Liquid Lubricant Additive for Tribological Behavior Improvement", Nanomaterials, pp. 1-12, 2020.

[18] Srivyas, P. D., \& Charoo, M. S.,"A Review on Tribological Characterization of Lubricants with Nano Additives for Automotive Applications",Tribology in Industri, pp. 594-623, 2018.

[19] Gajrani, K. K., \& Sankar, M. R.,"Past and Current Status of Eco-Friendly Vegetable Oil Based Metal Cutting Fluids", Materials Today: Proceeding, vol. 4, pp. 3786-3795, 2017.

[20] Yadgarov, L., Petrone, V., Rosentsveig, R., Feldman, Y., Tenne, R., \& Senatore, A., "Tribological studies of rhenium doped fullerene-like MoS2 nanoparticles in 
boundary, mixed and elasto-hydrodynamic lubrication conditions ", Wear, vol. 297(12), pp. 1103-1110, 2013.

[21] ASTM, G 99 -95a (Standard Test Method for Wear Testing with a Pin-on-Disk Apparatus), ASTM International, pp. 1-6, 2000.

[22] Arumugam, S., and Sriram, G.,"Synthesis and characterization of rapeseed oil biolubricant-its effect on wear and frictional behavior of piston ring-cylinder liner combination". Proceedings of the Institution of Mechanical Engineers, Part J: Journal of Engineering Tribology, vol. 227 (1), pp. 3-15, 2013.

[23] Charoo, M., Wani, M., Hanief, M., and Rather, M.,'Tribological Properties of MoS2 Particels as Lubricant Additive on EN31 Alloy Steel and AISI 52100 Steel Ball”, Materials Today: Proceedings, vol. 4, pp. 9967-9971, 2017.

[24] Shahabuddin, M., Masjuki, H.H., Kalam, M.A., Bhuiya, M.M.K., Mehat, H., "Comparative tribological investigation of bio-lubricant formulated from a non-edible oil source (Jatropha oil)", Industrial corps and Products, pp 323-330, 2013.

[25] Sharma, A. K., Tiwari, A. K., Singh, R. K., and Dixit, A. R.,"Tribological Investigation of TiO2 Nanoparticle based Cutting Fluid in Machining under Minimum Quantity Lubrication (MQL)", Recent Advances In Nano Science And Technology, pp. 2155-2162. 2019.

[26] Habibullaha, M., Masjukia, H. H., Kalama, M. A., Ashrafula, A. M., Habibb, M. A., Mobaraka, H. M., "Effect of bio-lubricant on tribological characteristics of steel", 10th International Conference on Mechanical Engineering, pp. 740 - 745, 2013.

[27] Sgroi, M., Gili, F., Mangherini, D., Lahouij, I., Dassenoy, F., Garcia, I., and Kraft, G.,'Friction reduction benefits in valve-train system using IF-MoS2 added engine oil", Tribology Transactions, vol. 58(2), pp. 207-214, 2015.

[28] Syahrullail, S., Kamitani, S., and Shakirin, A.,"Performance of Vegetables Oil as Lubricant in Extreme Pressure Condition”, Procedia Engineering, vol. 68, pp. 172-177, 2013.

[29] Singh, A., Prashant, C., Mamatha, T.G.,"A review on tribological performance of lubricants with nanoparticles Additives", Material Today, vol. 25(4), pp. 586-591, 2020.

[30] Shashidhara, Y.M., Jayaram, S.R.,"Vegetable oil sasa potential cutting fluid An evolution”, Tribology International, vol. 43, pp. 1073-1081, 2010.

[31] Farfan-Cabrera, L. I., Gallardo-Hernándezb, E.A., Pérez-Gonzálezc, J., Marín-Santibáñezd, B.M., Lewise, R., "Effects of Jatropha lubricant thermooxidation on the tribological behaviour of engine cylinder liners as measured by a reciprocating friction test", Wear, vol. 426-427, pp. 910-918, 2019. 
[32] Gunda, R. K., and Narala, S. K. R.,"Evaluation of friction and wear characteristics of electrostatic solid lubricant at different sliding conditions", Surface \& Coatings Technology, vol. 332, pp. 341-350, 2017.

[33] Krishna, V. P., Srikant, R.R., Rao, D.N., "Experimental investigation on the performance of nanoboric acid suspensions in SAE-40 and coconut oil during turning of AISI 1040 steel", International Journal of Machine Tools \& Manufacture,vol. 50(10), pp. 911-916, 2010.

[34] Hanifuddin, M., Fibria, M., and Widodo, S.,"Pengembangan Aditif Nano untuk Meningkatkan Kinerja Minyak Lumas", ESDM, Buku Tahunan Litbang ESDM 2016, Jakarta: Puslitbang ESDM, pp. 82-85, 2016.

[35] Kanagasabapathi, N., Balamurugan, K., and Mayilsamy, K., "Wear and thermal conductivity studies on nano copper particle suspended soya bean lubricant", Journal of Scientific and Industrial Research (JSIR), vol. 71, pp. 492-495, 2012. 